\title{
Pathogenesis of gall-rust disease on Falcataria moluccana in areas affected by Mount Merapi eruption in Indonesia
}

\author{
SRI RAHAYU", WIDIYATNO, DWI TYANINGSIH ADRIYANTI \\ Department of Silviculture, Faculty of Forestry, Universitas Gadjah Mada. Jl. Agro No. 1, Bulaksumur, Sleman 55281, Yogyakarta, Indonesia \\ Tel./fax.: +62-274-550541, "email: tatarahayu@ yahoo.com
}

Manuscript received: 14 December 2019. Revision accepted: 5 March 2020.

\begin{abstract}
Rahayu S, Widiyatno, Adriyanti DT. 2020. Pathogenesis of gall-rust disease on Falcataria moluccana in areas affected by Mount Merapi eruption in Indonesia. Biodiversitas 21: 1310-1315. The gall rust pathogen Uromycladium falcatarium affects the fastgrowing tree species Falcataria moluccana (Sengon) from seedling to mature stage producing galls on all its parts. Severe infestation causes tree mortality. There were two eruptions of the volcano at Mount Merapi, Java, Indonesia during October-November 2010 near to which Sengon is grown under community forests. This study, conducted in 2014, examined the implications of the volcanic eruptions on the incidence and severity of gall rust disease on Sengon trees growing in areas affected by the eruption. It revealed that the percentage infestation on seedlings caused by teliospores of $U$. falcatarium collected from areas close to Mount Merapi (3-7 km awayrisky area) was significantly higher compared to those collected from trees 7.1-11 (are under alert) and 11.1-15 km (area under threat) away. The teilospores and galls collected from the 'risky area' also exhibited morphological variations. The gall rust incidence on different parts of the tree was significantly higher in the 'risky' area compared to trees growing in other areas. The incidence of the disease was close to $100 \%$ in the risky area but less than $80 \%$ in areas 'under alert and under threat'. Overall, the data indicated that the incidence and severity of gall rust disease was significantly higher in areas close to the Mount Merapi apparently due to increased virulence of the pathogen and increased susceptibility of the trees due to damges caused by the eruption. Conducive environmental conditions such as high relative humidity and temperature in the area may also have favoured this situation. Artifical inoculations using teliospores collected from infected trees in the risky area, area under alert and under threat caused severe infection on seedlings.
\end{abstract}

Keywords: Fabaceae, plant health, rehabilitation, Uromycladium falcatarium, volcano

\section{INTRODUCTION}

Pyroclastic flow from eruptions of the volcano Mount Merapi in Central Java, Indonesia on October 26 and November 5, 2010 resulted in considerable damage to the surrounding Sengon (Falcataria moluccana (Miq.) Barneby and J.W. Grimes) community forests which were already affected by gall rust disease caused by Uromycladium falcatarium Doungsa-ard, McTaggart \& R.G. Shivas (Indresputra et al. 2013; Doungsa-Ard 2015). The eruption of Mount Merapi produced a complex of disturbance agents, such as pyroclastic flow, debris avalanche, mudflow, ash deposits, blowdown, and several other agents which interacted at specific sites exacerbating the degree of damage and delay in recovery (Adams et al. 1980; Dale et al. 1998; Franklin et al. 1985; del Moral 1993). Moreover, the pyroclastic flow from Mount Merapi apparently destroyed flora and fauna that it contacted in the surrounding area of the volcano. about two years after the eruption, surviving trees displayed a more intensive development of gall rust symptoms than one year before the eruption; tumors were of greater size, more reddish in color and showed faster maturity and active teliospore production (Indresputra et al. 2013). Environmental factors such as temperature and humidity are very influential in determining the success of basidiospores establishment (Rahayu et al. 2018) and will be very affecting in the subsequent process of pathogenesis, such as penetration and invasion.

Falcataria moluccana, a large tree native to Indonesia, Papua New Guinea, the Solomon Islands, and Australia, is widely distributed throughout south-east Asia and the Pacific Islands (Soerianegara and Lemmens 1993; Orwa et al. 2009; Wagner et al. 1999). It is a multi-purpose species planted in community forests around Mount Merapi. However, the tree is affected by gall rust which produces chocolate brown, cauliflower or whip-like galls on its stem, branches, petioles, leaves and pods (Rahayu et al. 2010). The disease causes severe damage to all developmental stages of $F$. moluccana from seedlings to mature trees. Affected plant parts and severely infected trees die prematurely (Braza 1997; Old and Cristovao 2003; Rahayu et al. 2010).

Against this background, the objectives of this study were: i) to evaluate the status of gall rust disease on young trees affected by Mount Merapi eruption and ii) ascertain pathogenicity of $U$. falcatarium teliospores collected from trees in areas affected by the eruption. 


\section{MATERIALS AND METHODS}

\section{Study area}

The study was conducted at 3 locations close to Mount Merapi in March 2014, approximately four years after the eruptions. These sites were located at i) ca. 3-7 km away from the top of Mount Merapi (TMM) (risky area), ii) 7.1$11 \mathrm{~km}$ away from TMM (area under alert), and iii) 11.1-15 $\mathrm{km}$ from TMM (area under threat) to southern direction. The sites were located around $07^{\circ} 22^{\prime} 33^{\prime \prime S}-07^{\circ} 52^{\prime} 30^{\prime \prime} \mathrm{S}$ and $110^{\circ} 15^{\prime} 00^{\prime \prime E}-110^{\circ} 37^{\prime} 30 " \mathrm{E}$.

\section{Methods}

Survey for disease occurrence

A survey for the occurrence and status of gall-rust on approximately two-year-old trees was conducted in three $20 \mathrm{~m} \times 20 \mathrm{~m}$ plots established at each of the three locations cited above. The trees, which the seedlings originated from local seed sources in Yogyakarta, were planted around early 2012 by local community. The variables measured were number of galls on each tree stem, branch and branch tip, and symptoms of gall-rust and galls on leaves (Table $1)$.

\section{Collection of spores and pathogenicity trials}

In order to understand the aggressivity of the rust fungus $U$. falcatarium after Merapi eruption, teliospores of U. falcatarium were collected from three locations i.e. risky area, area under alert, and area under threat. The sites were located around $07^{\circ} 22^{\prime} 33^{\prime \prime} \mathrm{S}-07^{\circ} 52^{\prime} 30^{\prime \prime} \mathrm{S}$ and $110^{\circ} 15^{\prime} 00^{\prime \prime} \mathrm{E}-$ $110^{\circ} 37^{\prime} 30^{\prime \prime E}$. Teliospore were collected from ten galls with similar maturity come from at least three surviving $\mathrm{F}$. moluccana trees after eruption.

The aggressivity of $U$. falcatarium was tested on threemonth-old healthy seedlings of $F$. moluccana (raised from seeds collected from the Wamena, Papua, known as tolerant seed source to $U$. falcatarium (Rahayu et al. 2009) in the greenhouse. The shoots of the seedlings were inoculated using a suspension-drop technique where $3 \mathrm{ml}$ of the spore suspension containing $5 \times 10^{6}$ teliospores per ml were placed on marked areas on individual shoots (Rahayu 2014). The experimental set up was a Complete Randomized Design (CRD) with nine replications using three inoculum sources (collected from risky, under alert and under threat areas). Three replications were used for histo-pathological assessment using disposable sample method, while six replications were used for assessing progression of symptoms on the inoculated seedlings. The ability of teliospores to germinate, penetrate and infect shoot tissue was observed in 1, 2, 3 and 4 hours after inoculation. One unit of observation contained 10 crosssections from each individual stems from the inoculated area. Histo-pathological assessment and teliospore performance were documented using ScopePhoto. Progression of symptoms was assessed based on the size of galls, $\mathrm{t}$ and seedling malformation and grouped into the following four categories (Table 2).

\section{Data analysis}

Data analyzed subjected to two-way analysis of variance (ANOVA), wherein PROC GLM was employed to test the significance of these random effects. All analyses were conducted using the statistical package in Statistical Analysis Systems (SAS) Institute Inc., v.9.13 (2004).

\section{RESULTS AND DISCUSSION}

\section{Occurrence of gall-rust on trees in areas affected by the volcano}

During eruptions of the volcano Mount Merapi on the end of 2010, most of flora, as well as F. moluccana trees planted by local people at the Mountain, were destroyed. Only small number of $F$. moluccana trees survived, but those were suffered due to gall rust diseases. About two years after eruption, local people, government also NGO have rehabilitated the affected area from about $3 \mathrm{~m}$ to $15 \mathrm{~m}$ from the top of Mount Merapi, mostly using F.moluccana species. Thus the evaluated trees, were the two years age of new-planted trees which the seed source was mostly from local seed source of Yogyakarta.

Based on the data collected during the survey, the gall rust severity on the tip, branch, leaf and total tree in the risky area was higher and significantly different compared to those in other areas. (Figure 1.A). However, the gall rust incidence on the stem was not significantly different between areas. This observation indicates that a large amount of inoculum present on the affected trees in the risky area was more aggressive and juvenile parts of the tree were extremely susceptible to the disease. The data on disease incidence showed that the gall rust was widespread in Merapi hill area. The incidence of the disease was close to $100 \%$ in the risky area but less than $80 \%$ in the other two areas (Figure 1.B). However, trees in all three areas were severely infested.

Table 1. Index score for presence of gall-rust in the field (Modified from Rahayu et al. (2011)

\begin{tabular}{clll}
\hline $\begin{array}{c}\text { Index } \\
\text { score }\end{array}$ & $\begin{array}{c}\text { Galls on stem tip and } \\
\text { branches }\end{array}$ & $\begin{array}{c}\text { Galls on the } \\
\text { stem }\end{array}$ & Symptoms and presence of galls on leaves in tree crown \\
\hline 0 & No galls & No galls & No symptom \\
1 & One to three galls & One gall & Curly leaves or small galls on $<25 \%$ leaf stalks in the crown \\
2 & Four to seven galls & Two galls & Curly leaves or small galls on $25-50 \%$ leaf stalks $25-50 \%$ in the crown \\
3 & Eight to ten galls & Three galls & Curly leaves or small galls on $50-75 \%$ leaf stalks $50-75 \%$ in the crown \\
4 & $>$ Ten galls & $>$ Three galls & Curly leaves or small galls on $75-100 \%$ leaf stalks in the crown \\
\hline
\end{tabular}




\section{Pathogenesis of $\boldsymbol{U}$. falcatarium on $\boldsymbol{F}$. moluccana seedlings}

There was an indication of slower initial germination of teliospores collected from the risky area. The germination percentage of teliospore from the risky area at one and two hours after inoculations showed lower than other localities. However, there was no significant difference $(P>0.05)$ in germination percentage of spores which was almost $100 \%$, for spores collected from all locations 3 hours after inoculation (Figure 2.A). Hence, there was significant difference $(\mathrm{P}<0.05)$ in percentage of penetration between each of the areas 1 hour after inoculation. Spores collected from areas distant from the eruption showed more penetration than those collected from the nearby areas (Figure 2.B). Conversely, percent infection was significantly greater $(\mathrm{P}<0.05)$ for teliospores collected from the risky area than other areas 2, 3 and 4 hours after inoculation and greater for the area under alert than for area under threat 4 hours after inoculation (Figure 2.C). Interestingly, there was no infection caused by teliospores collected from the risky area and area under alert $1 \mathrm{~h}$ after inoculation. Hence, the performance of germinated and penetrated teliospores from the risky area and area under alert were still normal, resulting in more infected tissues caused by mycelia from the risky area than under alert area (Figures 4-5).

\section{Discussion}

The rust fungus forming galls on $F$. moluccana, was previously identified as Uromycladium tepperianum (Sacc.) McAlp. in some countries in South-east Asia, including the Philippines, East Timor and Malaysia (Brown 1993; Braza 1997; Old and Cristovao 2003; Rahayu et al. 2010.). U. tepperianum was found to be a species complex and the rust on $F$. moluccana was described as Uromycladium falcatarium through molecular studies (Doungsa-ard et al. 2015). The identity of the rust fungus on $F$. moluccana in Java was also confirmed as $U$. falcatarium (Diputra 2016, pers. comm.). According to Indresputra et al. (2013), the pathogen collected from trees on the high hill of Merapi was more virulent compared to its virulence tested before the eruption of the volcano. However, his observations were not supported by any planned experiments and observations.

The success of infection by a plant pathogen is strongly influenced by the virulence of the pathogen, vulnerability

Table 2. Index score for development of gall-rust symptoms in the field

\begin{tabular}{cl}
\hline $\begin{array}{c}\text { Index } \\
\text { score }\end{array}$ & \multicolumn{1}{c}{ Symptoms } \\
\hline 0 & No symptom \\
1 & $\begin{array}{l}\text { Discolored and curly leaves } \\
\text { Discolored and curly leaves, twisted apical meristem, } \\
\text { and galls on the leaf }\end{array}$ \\
3 & $\begin{array}{l}\text { Discolored and curly infected leaves, f twisted apical } \\
\text { meristem and galls on the leaf and stem } \\
\text { Discolored and curly leaves, twisted apical meristem } \\
\text { and larger galls on the leaf and stem, stunted growth } \\
\text { of seedlings or mortality. }\end{array}$ \\
\hline
\end{tabular}

of the host, and the environment. This is supported by the production of gall rust symptoms on seedlings inoculated in the greenhouse. Moreover, there were visible variations between germination of teliospores, penetration of basidiospores and intensity of mycelial growth in stem tissues produced by the inoculum collected from risky and alert areas (Figures 3-4). Teliospores originated from the risky area were able to occupy a large portion of the host tissue one hour after inoculation (indicated by blue staining with cotton blue). Whereas, teliospores originated from other areas were able to occupy only a small area (Figures 3-4). The condition was likely related to the character of the rust fungus as an obligate parasite. According Hahn (2000) and Garnica et al. (2014), after getting inside the host tissue, the penetration hypha forms a substomatal vesicle from which an infection hypha differentiates; then a haustorium mother cell starts forming a penetration peg that secretes cell wall- degrading enzymes to penetrate the host cell wall in order to differentiate a haustorium within the host cell cavity. The haustorium is an invagination within the host cell plasmalemma, which remains intact. Regarding to extreme environmental changing when Mount Merapi erupted, thus the activity of rust fungus from the risky area may be adapted to be slower in their activity inside the cells. However, after they established inside the cells, the mycelia will develop rapidly and severely at two hours after inoculation. Thus, regarding pathogenesis investigated in the Laboratory, it is proved that teliospores of $U$. falcatarium from the risky area were more aggressive weather they need more time for infection.

According to Indesputra et al. (2013), the morphology of the teliospores originated from the risky area was different compared to those originated from other areas. They were bigger in size, brighter, and had a better shape (more roundish). These observations show that $U$. falcatarium spores collected from the risky area were different morphologically but more virulent on $F$. moluccana in the field. According to Hoff (1986) high elevation areas such as risky area as above, having foggy conditions and intermittent showers which favor rust development. This is further proved by the significantly high incidence and severity of gall rust on the existing young trees at the risky area compared to 'area under alert' and 'area under threat' (Figure 4.A-B).

Table 3. Status of gall-rust disease incidence (DI) and severity (DS) in the field

\begin{tabular}{clcl}
\hline DI & $\begin{array}{c}\text { Status of } \\
\text { incidence }\end{array}$ & DS & $\begin{array}{c}\text { Severity } \\
\text { status }\end{array}$ \\
\hline$<10 \%$ & Rare & $0 \%$ & Nil \\
$10-<25 \%$ & Occasional & $<25 \%$ & Low \\
$25-<50 \%$ & Common & $25-<50 \%$ & Medium \\
$50-<75 \%$ & Very common & $50-<75 \%$ & Severe \\
$>75 \%$ & Widespread & $75-100 \%$ & Very severe \\
\hline
\end{tabular}




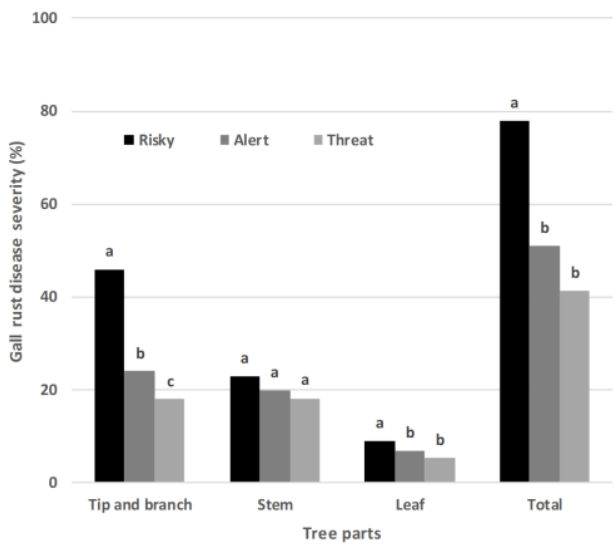

A

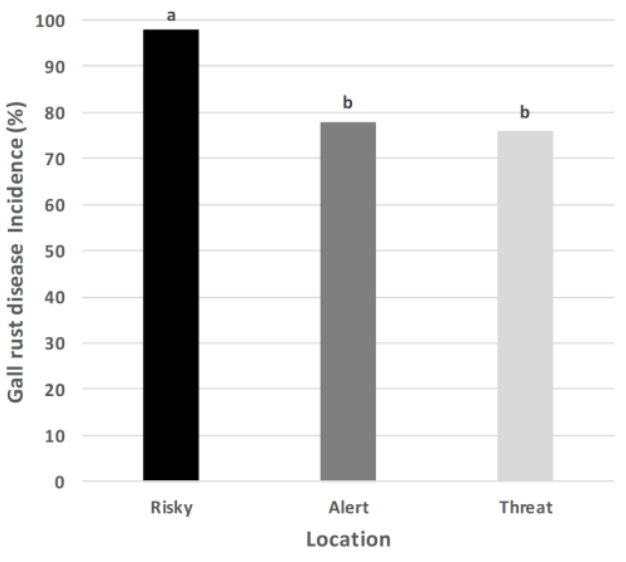

B

Figure 1. A. Gall rust disease a. severity on the tip and or branch, stem and leaf also total, B. Incidence on one year $F$. moluccana on risky area and area under alert at Mount Merapi, Indonesia

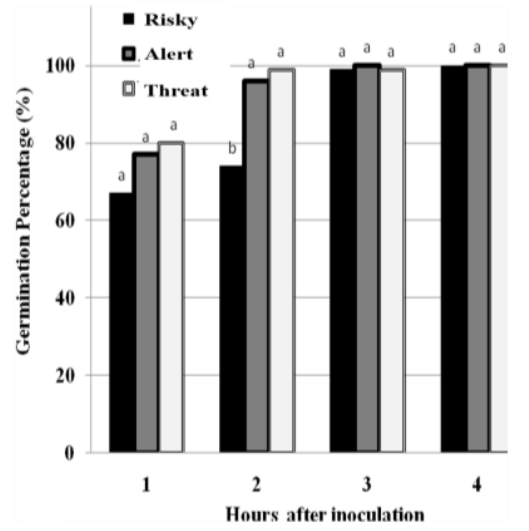

A

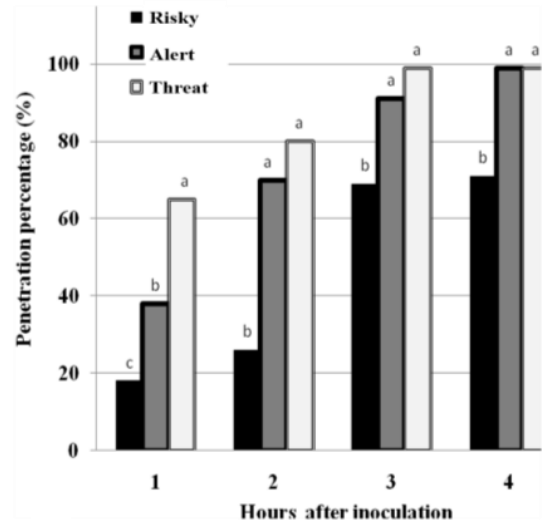

B

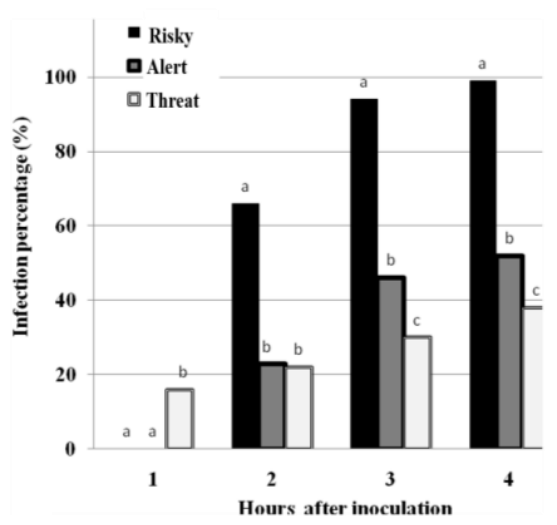

$\mathbf{C}$

Figure 2. Percent of germination (A), penetration (B) and infection (C) of $U$. falcatarium teliospores from the risky area, area under alert and area under threat, following artificial inoculation on $F$. moluccana seedlings under laboratory control
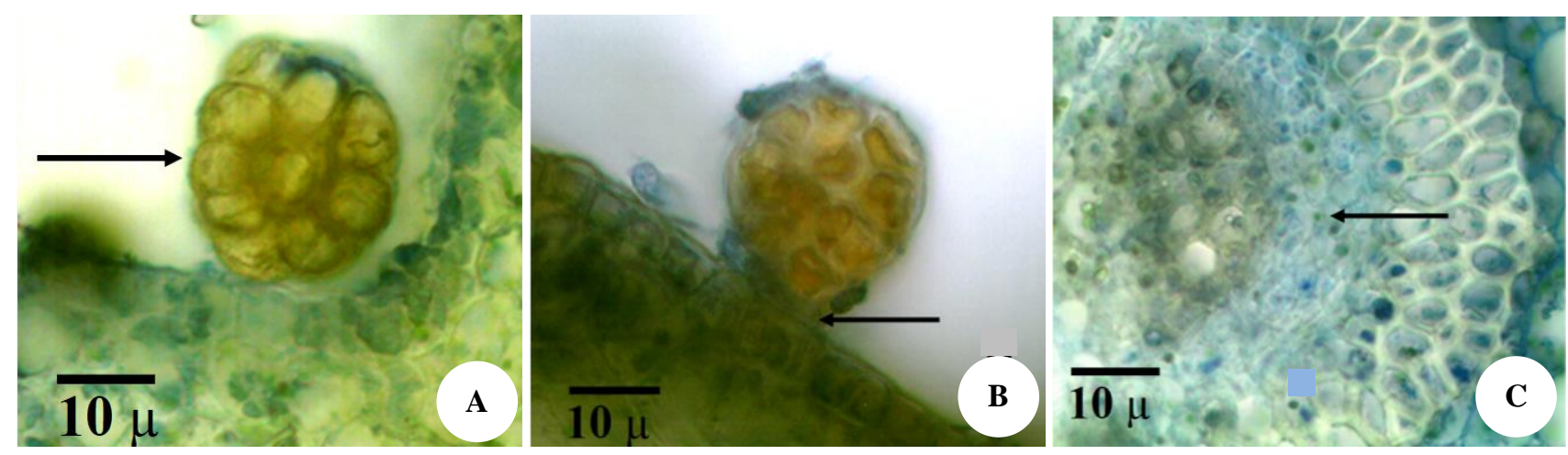

Figure 3.A. Teliospore germination, B. Basidiospore penetration, and C. Infected tissue with mycelia following inoculation of seedlings of F. moluccana by $U$. falcatarium by teliospores from risky area (Magnified 400x) 

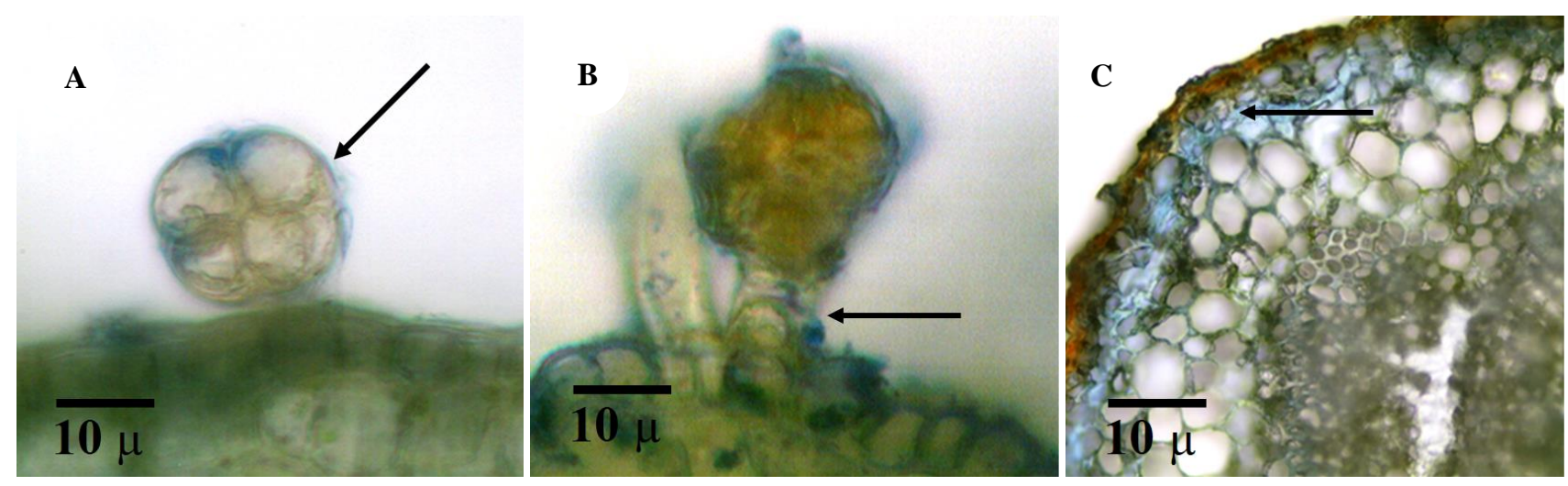

Figure 4.A. Teliospores germination, B. Basidiospore penetration, and C. Infected tissue with mycelia following inoculation of seedlings by $U$. falcatarium mycelia, from area under alert (Magnified 400x)
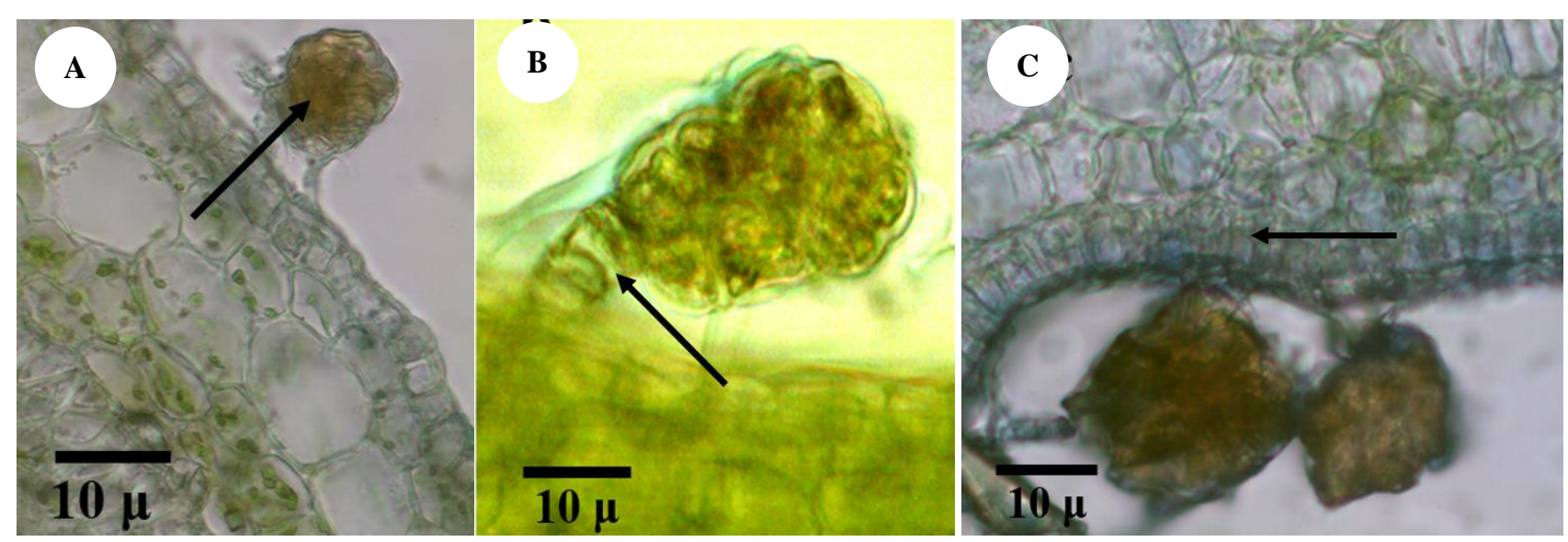

Figure 5.A. Teliospores germination, B. Basidiospore penetration, and C. Infected tissue with mycelia following inoculation of seedlings by $U$. falcatarium mycelia, from area under threat (Magnified 400x)

However, in the field condition, this condition may not only be due to the aggressivity of the $U$. falcatarium at the sites but also by the susceptibility of the host weakened by the impact of volcanic eruption and the prevailing environmental conditions which are conducive for disease development. It is well known that plant diseases occur when susceptible host plants, virulent pathogens, and conducive environmental conditions coincide (Barrett et al. 2009; Garrett et al. 2009). According to Rahayu (2018), relative humidity and wind speed were two dominant environmental conditions supporting gall rust disease development. French (1992) recorded that Uromycladium teliospores required a humid atmosphere for germination. In short, all these conditions promoted rapid development of disease on the sites planted with $F$. moluccana.

Based on qualitative data, including continued evaluation of symptoms in the field, it was clear that the majority of seedlings in the Merapi hill area were killed due to rust disease. In nurseries of $F$. moluccana in the Philippines, the affected seedlings usually lost their leaves and became stunted and eventually killed-the mortality was around 90-100\% (De Guzman et al. 1991). Rahayu et al. (2006) observed the occurrence of gall rust on the stem, shoot, and leaf of two-month-old seedlings of $F$. moluccana transplanted in the field. The disease caused70$80 \%$ mortality of seedlings in Java, Indonesia.

Active volcanoes are present in some of the south-east Asian countries like Indonesia. Eruption of these which affect ecosystems in proximity to the volcanoes resulting in local climate change and increased susceptibility of vegetation to plant pathogens, fire and insect attack (Ayres and Lombardero 2000). The increased susceptibility of $F$. moluccana to the gall rust pathogen Uromycladium falcatarium is a case in point. It thus appears that $F$. moluccana is not a suitable species for rehabilitation in volcano affected areas.

In summary, the incidence and severity of gall rust were significantly higher in areas close to and affected by Mount Merapi eruption. Increased susceptibility of the plant and enhanced virulence of the pathogen may be the probable cause for the high incidence of the disease in the volcano affected areas. Other critical factors for high occurrence and increased gravity of the disease included favorable environmental conditions such as high humidity, wind speed, and high atmospheric temperature. 


\section{ACKNOWLEDGEMENTS}

This research was funded by the Indonesian Directorate General of Higher Education through Universitas Gadjah Mada, Yogyakarta, Indonesia under contract No. 184/LPPM/2014. Technician and bachelor student as enumerator for their contribution to data collected.

\section{REFERENCES}

Adams AB, Dale VH, Kruckeberg AR, Smith E. 1987. Plant survival, growth form, and regeneration following the May 18, 1980, eruption of Mount St. Helens, Washington. Northwest Sci 6: 160-170.

Ayres MP, Lombardero MJ. 2000. Assessing the consequences of global change for forest disturbance from herbivores and pathogens. Sci Total Environ 262 (3): 263-286.

Barrett LG, Kniskern JM, Bodenhausen N, Zhang W, Bergelson J. 2009. Continua of specificity and virulence in plant host-pathogen interactions: causes and consequences. New Phytol 183: 513-529.

Braza RD. 1997. Gall rust disease of Paraserianthes falcataria in the Philippines. For Farm Community Tree Res Rep 1997 2: 61-62.

Brown B. 1993. Current and Potential Diseases of FastGrowing Industrial Timber Plantation Trees. Mandala Agriculture Development Corporation (MADECOR), Jakarta. [Indonesian]

Dale VH, Lugo AE, MacMahon JA, Picket ST, Pickett A. 1998. Management in the Context of Large, Infrequent Disturbances. Ecosystems 1:546-557.

De Guzman ED, Militante EP, Lucero R. 1991. Forest nursery diseases and insects in the Philippines. In: Sutherland JR, Glover SG (eds.). Proceedings of the first meeting of IUFRO working party S2.07-09 (diseases and insects in forest nurseries). Victoria, British Columbia [Canada]

Del Moral R. 1993. Mechanisms of primary succession on volcanoes: a view from Mount St. Helens. In: Miles J, Walton DH (eds.). Primary succession on land. Blackwell Scientific, Oxford, pp.79-100.

Doungsa-Ard C, McTaggart AR, Geering ADW, Dalisay TU, Ray J, Shivas RG. 2015. Uromycladium falcatarium sp. nov., the cause of gall rust on Paraserianthes falcataria in south-east Asia. Australas Plant Pathol 44: 25-30.

Franklin JF, MacMahon JA, Swanson FJ, Sedell JR. 1985. Ecosystem responses to the eruption of Mount St. Helens. Nat Geogr Res 1: 198216

French RC. 1992. Volatile chemical germination stimulators of rust and other fungal spores. Mycologia 84: 277-288.

Garnica DP, Nemri A, Upadhyaya NM, Rathjen JP, Dodds PN. 2014. The ins and outs of rust haustoria. PLoS Pathog 10 (9): e1004329. DOI: 10.1371/journal.ppat.1004329.
Garrett KA, Nita M, De Wolf ED, Gomez L, Sparks AH. 2009. Plant pathogens as indicators of climate change. In: Letcher TM (eds) Climate change: observed impacts on planet Earth. Elsevier, Amsterdam.

Hahn M. 2000. The rust fungi. In: Fungal Pathology. Springer, Dordrecht.

Hoff RJ. 1986. Susceptibility of pine populations to western gall rust-central Idaho (Vol. 354). US Department of Agriculture, Forest Service, Intermountain Research Station, Washington, DC.

Indresputra F, Rahayu S, Widiyatno. 2013. Effect of pyroclastic cloud from Merapi volcano to the survival of Uromycladium falcatarium on Falcataria moluccana in Yogyakarta, Indonesia. Procedia Environ Sci 17 (2013) 70-78

Old KM, Cristovao CS. 2003. A rust epidemic of the coffee shade tree (Paraserianthes falcataria) in East Timor. ACIAR Proc 13: 139. 145.

Orwa C, Mutua A, Kindt R, Jamnadass R, Simons A. 2009. Agroforestree Database: a tree reference and selection guide. Version 4. Agroforestree Database: a tree reference and selection guide. Version 4.

Rahayu S, Lee SS, Nor Aini AS. 2010. Uromycladium falcatarium, the gall rust fungus from Falcataria moluccana (Miq.) Barneby and J.W. Grimes in Malaysia and Indonesia. J Mycosci 51: 149-153. DOI 10.1007/s10267-009-0022-2.

Rahayu S, Lee SS, Nor Aini AS. 2011. Gall Rust Disease of Falcataria moluccana: characterization of the pathogen, environmental condition supported, genetic relationship and screening for resistance. Lambert Academic Press, Germany.

Rahayu S, Lee SS, Nor Aini AS, Gizan S, Ahmad SS. 2006. Infection of Falcataria moluccana (Miq.) Barneby \& Grimes seedling by gall rust fungus Uromycladium spp. is associated with a reduction in growth and survival. Proceeding of International Post Graduate Student Conference. University Science Malaysia (USM), Penang. [Malaysia]

Rahayu S, Lee SS, Shukor NAA, Saleh G. 2018. Environmental Factors Related to Gall Rust Disease Development on Falcataria moluccana (Miq.) Barneby \& J.W. Grimes at Brumas Estate, Tawau, Sabah, Malaysia. J Ecol Environ Res 16 (6): 7485-7499.

Rahayu S, Shukor NAA, See LS, Saleh G. 2009. Responses of Falcataria moluccana seedlings of different seed sources to inoculation with Uromycladium tepperianum. Silvae Genetica 58 (1-6): 62-68.

Rahayu S. 2014. Strategi pengelolaan penyakit tanaman hutan di Indonesia: penyakit karat tumor pada tanaman sengon (Falcataria moluccana). Gadjah Mada University Press, Yogyakarta. [Indonesian]

Soerianegara I, Lemmens RHMJ. 1993. Plant Resources of Southeast Asia. No. 5 (1). Timber Trees: Major Commercial Timbers. Prosea, Bakhuys, Leyden.

Wagner WL, Herbst DR, Sohmer SH. 1999. Manual of the flowering plants of Hawaii. University of Hawaii Press, Honolulu. 